\title{
Two Distinct Signaling Pathways Upregulate NMDA Receptor Responses via Two Distinct Metabotropic Glutamate Receptor Subtypes
}

\author{
Pascal Benquet, Christine E. Gee, and Urs Gerber \\ Brain Research Institute, University of Zurich, $\mathrm{CH}$-8057 Zurich, Switzerland
}

\begin{abstract}
Molecular processes regulating the gain of NMDA receptors modulate diverse physiological and pathological responses in the CNS. Group I metabotropic glutamate receptors (mGluRs), which neighbor NMDA receptors and which can be coactivated by synaptically released glutamate, couple to several different second messenger pathways, each of which could target NMDA receptors. In CA3 pyramidal cells we show that the activation of mGluR1 potentiates NMDA current via a G-protein-independent mechanism involving Src kinase activa-
\end{abstract}

tion. In contrast, mGluR5-mediated enhancement of NMDA current requires G-protein activation, triggering a signaling cascade including protein kinase $\mathrm{C}$ and Src. These results indicate that one neurotransmitter, glutamate, can activate two distinct and independent signaling systems to target the same effector. These two pathways are likely to contribute significantly to the highly differentiated control of NMDA receptor function.

Key words: mGluR1; mGluR5; Src tyrosine kinase; PKC; G-protein-independent signaling; potentiation; hippocampus
Glutamatergic signaling via NMDA receptors is essential for CNS function, controlling a wide range of responses from neuronal development to synaptic plasticity. Accordingly, sensitive mechanisms are in place to fine-tune NMDA responses, allowing for the adaptation of gain to ambient requirements. An immediate form of NMDA receptor modulation is mediated by postsynaptic metabotropic glutamate receptors (mGluRs), which frequently neighbor NMDA receptors (Baude et al., 1993; Lujan et al., 1996, 1997). Although interactions between mGluRs and NMDA receptors first were described a decade ago, past studies reached conflicting conclusions as to whether the stimulation of mGluRs potentiates NMDA receptor activity (Aniksztejn et al., 1991; Bleakman et al., 1992; Harvey and Collingridge, 1993) (for review, see Anwyl, 1999; Valenti et al., 2002) or inhibits NMDA responses (Yu et al., 1997; Wang et al., 1998; Zhong et al., 2000; Snyder et al., 2001). There is, however, general agreement that the postsynaptic mGluRs involved in NMDA response modulation belong to Group I, either mGluR1 (Lan et al., 2001; Skeberdis et al., 2001; Heidinger et al., 2002) or mGluR5 (Doherty et al., 1997, 2000; Jia et al., 1998; Awad et al., 2000; Mannaioni et al., 2001; Pisani et al., 2001).

A further unresolved issue is the mechanism underlying the modulation of NMDA receptors by mGluRs. Group I mGluRs are coupled positively via G-proteins to phospholipase C (PLC), leading to the formation of diacylglycerol (DAG) and protein kinase $\mathrm{C}(\mathrm{PKC})$ activation and to the production of inositol trisphosphate $\left(\mathrm{IP}_{3}\right)$, resulting in the release of $\mathrm{Ca}^{2+}$ from intra-

Received June 11, 2002; revised Sept. 3, 2002; accepted Sept. 4, 2002.

This work was funded by the Swiss National Science Foundation and the National Center of Competence in Research on Neural Plasticity and Repair. We thank Beat Gähwiler for his continuous support and for providing us with slice cultures. We thank H. Blum, S. Giger, H. Kasper, A. Nussbaumer, L. Rietschin, and R. Schöb for excellent technical assistance, and B. Gähwiler, M. Mori, and M. Scanziani for helpful discussions and a critical reading of this manuscript.

Correspondence should be addressed to Urs Gerber, Brain Research Institute, University of Zurich, Winterthurerstrasse 190, CH-8057 Zurich, Switzerland. E-mail: gerber@hifo.unizh.ch.

Copyright ( 2002 Society for Neuroscience 0270-6474/02/229679-08\$15.00/0 cellular stores (Conn and Pin, 1997). In addition, mGluRs can signal via direct membrane-delimited pathways whereby G-protein subunits may modulate ion channels directly (Swartz and Bean, 1992; Trombley and Westbrook, 1992; McCool et al., 1996; Yu et al., 1997) and via G-protein-independent transduction, resulting in Src tyrosine kinase activation (Heuss et al., 1999). This diversity of second messenger systems, all of which may target NMDA receptors, is suggestive of a complex intracellular network capable of subtle regulation of NMDA receptor function. Several earlier studies presented evidence for a PKCdependent pathway in the potentiation of NMDA responses by mGluRs (Aniksztejn et al., 1991; Kelso et al., 1992; Pisani et al., 1997; Ugolini et al., 1997; Skeberdis et al., 2001), but other investigators reported a PKC-independent process (Harvey and Collingridge, 1993; Kinney and Slater, 1993; Rahman and Neuman, 1996; Holohean et al., 1999). An established mechanism underlying NMDA receptor upregulation involves tyrosine phosphorylation of the receptor via Src kinase (Salter, 1998), and a signaling cascade involving PLC, PKC, and Src has been shown to target NMDA receptors (Lu et al., 1999; Huang et al., 2001). It is not known, however, whether the activation of mGluRs can initiate this pathway.

Here we systematically assessed the role of the major transduction pathways coupled to Group I mGluRs in regulating NMDA receptors. Experiments were performed in hippocampal CA3 pyramidal cells, which express both subtypes of Group I metabotropic receptors, permitting us to evaluate the effects of selective activation of either mGluR1 or mGluR5 in the same system.

\section{MATERIALS AND METHODS}

Slice culture preparation and electrophysiology. Hippocampal slice cultures were prepared from 6-d-old Wistar rats as described previously (Gähwiler et al., 1998) and maintained by using the roller-tube technique. After 2-3 weeks in vitro the slice cultures were transferred to a recording chamber with a volume of $1 \mathrm{ml}$ on an upright microscope (Axioscope FS; Zeiss, Oberkochen, Germany). Slices were superfused continuously at a rate of $1-2 \mathrm{ml} / \mathrm{min}$ with saline containing (in $\mathrm{mm}$ ) $137 \mathrm{NaCl}, 2.7 \mathrm{KCl}$, 11.6 $\mathrm{NaHCO}_{3}, 0.36 \mathrm{NaH}_{2} \mathrm{PO}_{4}, 0.48 \mathrm{MgCl}_{2}, 1.8 \mathrm{CaCl}_{2}$, and 5.6 D-glucose 
plus $0.5 \mu \mathrm{M}$ tetrodotoxin (TTX) and $10 \mathrm{mg} / 1$ phenol red $\mathrm{pH}$-adjusted to 7.4 , with an osmolarity of $\sim 310 \mathrm{mOsm}$ and a bath temperature of $29^{\circ} \mathrm{C}$. Whole-cell voltage-clamp recordings were obtained from CA3 pyramidal neurons held at $-50 \mathrm{mV}$ with an Axopatch 200A amplifier (Axon Instruments, Foster City, CA). Recording pipettes (2-5 M $\Omega$ ) were filled with (in mM) $130 \mathrm{~K}$-gluconate, $10 \mathrm{NaCl}, 1 \mathrm{MgCl}_{2}, 10 \mathrm{HEPES}, 10$ EGTA, and $4 \mathrm{Mg}$-ATP (pH-adjusted to 7.3 with $\mathrm{KOH}$; osmolarity $\sim 300 \mathrm{mOsm}$ ). In the indicated experiments $10 \mathrm{~mm}$ EGTA was replaced with $10 \mathrm{~mm}$ BAPTA. Series resistance (6-13 M $\Omega$ ) and input resistance were monitored regularly. Currents were filtered at $2 \mathrm{kHz}$ and analyzed off-line (pClamp 7; Axon Instruments).

Induction of NMDA currents. NMDA currents were isolated pharmacologically by adding the AMPA/kainate antagonist 1,2,3,4-tetrahydro6-nitro-2,3-dioxo-benzo[f]quinoxaline-7-sulfonamide (NBQX; $40 \mu \mathrm{M}$ ) and the GABA $\mathrm{A}_{\triangle}$ receptor antagonist picrotoxin $(100 \mu \mathrm{M})$. NMDA current amplitudes were measured from baseline holding current to peak. The maximum percentage of potentiation is the average value of at least two NMDA current traces obtained during the peak effect of the agonists and normalized with respect to the average NMDA current measured in the three to five traces immediately preceding the application of agonists (referred to as "baseline"). $I-V$ curves of the NMDA response were determined with a ramp protocol from -70 to $0 \mathrm{mV}$ ( $2 \mathrm{sec}$ duration). The ramp protocol was run before and during NMDA pressure application, and the respective traces were subtracted to obtain the $I-V$ curve of the NMDA response in control. Then the same procedure was repeated after the application of DHPG.

To determine whether potentiation of NMDA current by drug treatment was significant, we used the paired Student's $t$ test on raw data. When the effects of two treatments were compared on different neurons, the unpaired Student's $t$ test was used. For multiple comparisons the percentage of potentiation for each condition was compared by using the one-way ANOVA, followed by Tukey's test. A value of $p<0.05\left({ }^{*}\right)$ was considered statistically significant and also $p<0.01(* *)$. All numerical data are expressed as the means \pm SEM.

Drugs. ( $S$ )-3,5-dihydroxyphenylglycine (DHPG), (1S,3R)-1-aminocyclopentane-trans-1,3-dicarboxylic acid (ACPD), (RS)-2-chloro-5-hydroxyphenylglycine (CHPG), 7-(hydroxyimino)cyclopropachromen-1a-carboxylateethyl ester (CPCCOEt), $(S)-(+)$ - $\alpha$-amino-4-carboxy-2-methylbenzeneacetic acid (LY367385), 2-methyl-6-(phenylethynyl)pyridine (MPEP), and 2-[1-(3-dimethylaminopropyl) indol-3-yl]-3-(indol-3-yl) maleimide (GF109203X) were purchased from Tocris Cookson (Bristol, UK). Guanosine 5'-O-(2-thiodiphosphate) trilithium salt (GDP $\beta S$ ), NMDA, picrotoxin, 4',5,7-trihydroxyisoflavone (genistein), and 4',7dihydroxyisoflavone (daidzein) were purchased from Sigma (St. Louis, MO). Phorbol 12-myristate 13-acetate (PMA), 1-(6-[([17 $\beta]-3-$ methoxyestra-1,3,5[10]-trien-17-yl)amino]hexyl)-1 $H$-pyrrole-2,5-dione (U-73122), and 4-amino-5-(4-methylphenyl)-7-(t-butyl)pyrazolo[3,4d]pyrimidine 1 (PP1) were purchased from Alexis (San Diego, CA). NBQX was obtained from AG Scientific (San Diego, CA) and TTX from Latoxan (Valence, France). 3- $((R)-2$-carboxypiperazin-4yl)propyl-1-phosphonic acid (CPP) and baclofen were kindly provided by Novartis (Basel, Switzerland). Stock solutions of DHPG, ACPD, GDP $\beta$ S, NMDA, TTX, and CPP were prepared by dissolving in water (for DHPG and GDP $\beta$ S freshly prepared every 14 and $3 \mathrm{~d}$, respectively). Stock solutions of CPCCOEt, MPEP, GF109203X, picrotoxin, baclofen, genistein, daidzein, PMA, U-73122, and PP1 were prepared in DMSO. The final concentrations of DMSO used during experiments never exceeded $0.02 \%$, which did not affect NMDA current potentiation ( $n=7$; see also experiments with daidzein). LY367385 stocks were dissolved in 1.1 equivalent $\mathrm{NaOH}$ but were diluted $1000 \times$ in experiments, resulting in no measurable change in $\mathrm{pH}$.

\section{RESULTS}

\section{Activation of group I mGluRs potentiates NMDA current}

As observed previously in numerous brain regions, we found that in CA3 pyramidal cells NMDA receptor-mediated currents were enhanced by the concomitant activation of mGluRs (Fig. 1). NMDA currents were induced repetitively in voltage-clamped CA3 pyramidal cells $(-50 \mathrm{mV})$ by applying brief pressure pulses (100-300 msec) to a micropipette filled with NMDA $(100 \mu \mathrm{M})$ at $40 \mathrm{sec}$ intervals. NMDA responses were blocked completely by the specific antagonist CPP (40 $\mu \mathrm{M} ; n=10 ; p<0.001)$. Position-

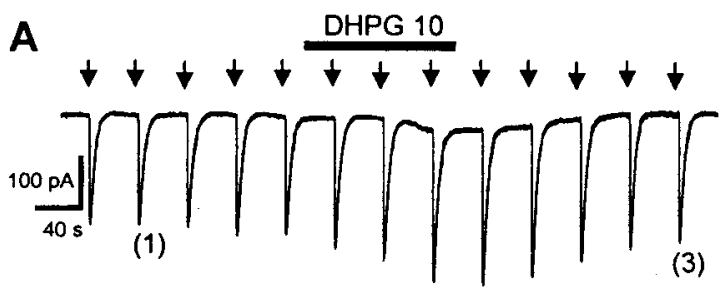

(2)
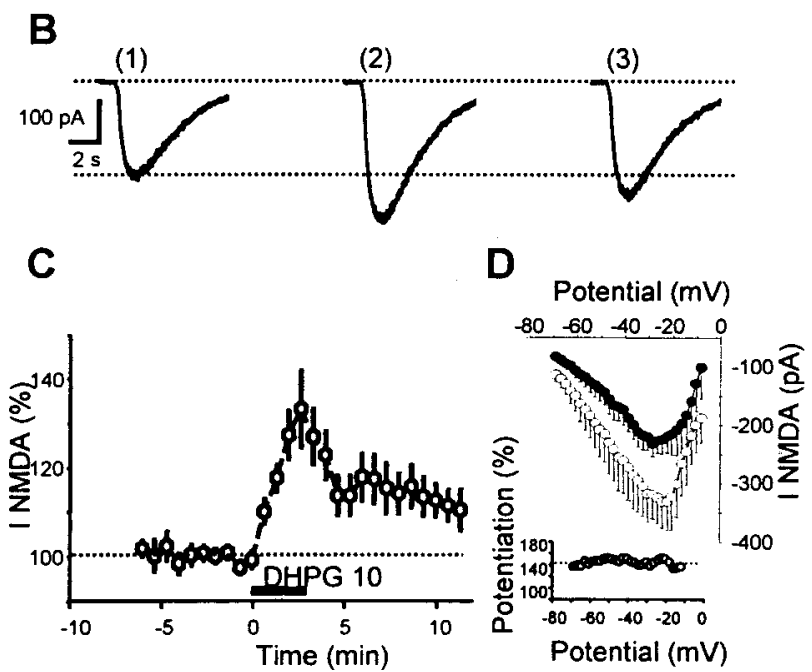

Figure 1. Activation of group I mGluRs potentiates currents mediated by NMDA receptors in CA3 pyramidal cells. $A$, NMDA currents induced by the pressure application of NMDA (100 $\mu \mathrm{M}$ for $200 \mathrm{msec})$ every $40 \mathrm{sec}$ (black arrows) are potentiated by the bath application of the specific group I mGluR agonist DHPG (10 $\mu \mathrm{M}$ for $2 \mathrm{~min})$. The effect is transient and reversible. $B$, Single NMDA current traces from the recording in $A$ shown at an expanded time scale before (1) during (2), and after (3) the washout of DHPG. $C$, Average time course of the DHPG-induced potentiation $(n=23)$. $D$, Average current-voltage relationship of NMDA responses obtained with a ramp protocol before (filled circles) and after (open circles) DHPG application $(n=5$; mean \pm SEM of current is shown every $2 \mathrm{mV})$. Inset shows subtraction of control $I-V$ plot from $I-V$ plot after the application of DHPG.

ing the puffer pipette at a distance of $\sim 100 \mu \mathrm{m}$ from the recorded cell in the absence of a pressure pulse did not alter the holding current. The presence of TTX, NBQX, and picrotoxin in the bath solution prevented the contamination of NMDA currents with synaptic responses. Under these conditions, brief reversible NMDA currents exhibiting minimal variations in amplitude could be induced routinely for 1-2 hr. After a steady baseline of NMDA responses was recorded, the application of the broad-spectrum mGluR agonist ACPD (50 $\mu \mathrm{M}$ for $4 \mathrm{~min}$ ) or the group I agonist DHPG (10 $\mu \mathrm{M}$ for $2 \mathrm{~min}$ ) increased the peak amplitude of NMDA currents by $22 \pm 4 \%(n=6 ; p<0.05$ vs baseline $)$ and $38 \pm 5 \%(n=23 ; p<0.001$ vs baseline $)$, respectively. This effect peaked rapidly, within $2 \mathrm{~min}$, but reversal after washout of metabotropic agonists was relatively slow (Fig. 1C). Apart from the potentiation of NMDA current, DHPG (10 $\mu \mathrm{M}$ for $2 \mathrm{~min})$ or ACPD (50 $\mu \mathrm{M}$ for $4 \mathrm{~min}$ ) induced an inward current associated with an increase in input resistance $(15 \pm 4 \%, n=19, p<0.01$ for DHPG; $13 \pm 4 \%, n=7, p<0.05$ for ACPD), as characterized previously (Guérineau et al., 1994). Repeated application of mGluR agonists to the same preparation induced reproducible responses. The potentiation of NMDA current induced by a second application of DHPG (10 $\mu \mathrm{M}$ for $2 \mathrm{~min})$ or ACPD $(50 \mu \mathrm{M}$ 
for $4 \mathrm{~min})$ corresponded to $93 \pm 6 \%(n=4 ; p>0.05)$ and $92 \pm$ $16 \%(n=5 ; p>0.05)$, respectively, of the previous potentiation. The extent of potentiation of the peak NMDA-evoked currents was independent of membrane potential over the range from -70 to $-10 \mathrm{mV}$ (Fig. $1 D$ ).

\section{Potentiation of NMDA current by mGluRs involves tyrosine kinase activation}

The application of Src to CA3 pyramidal cells increases NMDA currents (Xiong et al., 1999). Moreover, the activation of mGluRs can lead to Src activation (Fiore et al., 1993; Siciliano et al., 1994; Heuss et al., 1999; Boxall, 2000; Peavy et al., 2001). We therefore tested whether the mGluR-dependent potentiation of NMDA current requires tyrosine kinase activation. We found that the DHPG-induced potentiation of NMDA current (41 $\pm 6 \%, n=5$; $p<0.05$ vs baseline) was reduced substantially after the application of the broad-spectrum tyrosine kinase antagonist genistein (30 $\mu \mathrm{M}$ for $15 \mathrm{~min} ; 8 \pm 8 \% ; p>0.05$ vs baseline and $p<0.01$ vs DHPG alone) (Fig. 2A2). The potentiation of NMDA current was insensitive to the inactive genistein analog daidzein $(30 \mu \mathrm{M}$ for $15 \mathrm{~min} ; 37 \pm 14 \%, n=5 ; p<0.05$ vs baseline) (Fig. 2A3). The application of PP1 ( $25 \mu \mathrm{M}$ for $15 \mathrm{~min}$ ), a specific inhibitor of Src kinase, also reduced the DHPG-induced potentiation of NMDA current $(58 \pm 12 \%$ before PP1 treatment, $p<0.05$ vs baseline compared with $11 \pm 6 \%$ after PP1 treatment; $n=5 ; p>0.05$ vs baseline and $p<0.01$ vs DHPG alone) (Fig. $2 B$ ). No effect on NMDA currents was observed when genistein or PP1 was applied alone, suggesting weak background phosphorylation of NMDA receptors in CA3 cells in our preparation.

\section{mGluR1 and mGluR5 mediate NMDA current potentiation}

In CA1 pyramidal cells and subthalamic neurons the enhancement of NMDA current by mGluRs is mediated by mGluR5, whereas mGluR1 activation is without effect (Awad et al., 2000; Mannaioni et al., 2001). We found a similar mGluR5-mediated potentiation of NMDA current in CA3 pyramidal cells. mGluR5 was stimulated either by applying the specific agonist CHPG (500 $\mu \mathrm{M}$ for $2 \mathrm{~min} ; n=8$ ) (Fig. $3 A$ ) or by applying the group I agonist DHPG (10 $\mu \mathrm{M}$ for $2 \mathrm{~min})$ in the presence of a saturating concentration of the mGluR1 antagonist CPCCOEt (50 $\mu \mathrm{M}$ for $10 \mathrm{~min}$; $n=6$ ) (Fig. 3B). Either approach resulted in a significant potentiation in the amplitude of NMDA current $(20 \pm 5 \%, p<0.05$ for CHPG vs baseline; $19 \pm 5 \%, p<0.05$ for DHPG plus CPCCOEt vs baseline). However, selective activation of mGluR5 resulted in significantly less potentiation than that observed with the coactivation of mGluR1 and mGluR5 with DHPG (DHPG plus CPCCOEt vs DHPG alone; $n=5 ; p<0.05$ ) (Fig. $3 D$ ). We therefore tested whether the selective activation of mGluR1 also increases NMDA currents. When DHPG (10 $\mu \mathrm{M}$ for $2 \mathrm{~min})$ was applied to cells in the presence of a saturating concentration of the mGluR5 antagonist MPEP (10 $\mu \mathrm{M}$ for $10 \mathrm{~min} ; n=5$ ) (Fig. 3C), NMDA current was potentiated significantly $(18 \pm 4 \% ; p<0.05$ vs baseline). Again, selective activation of mGluR1 induced less potentiation than the coactivation of mGluR1 and mGluR5 (DHPG plus MPEP vs DHPG; $n=5 ; p<0.01$ ). Thus both mGluR1 and mGluR5 mediate NMDA current potentiation in CA3 pyramidal cells (Fig. 3D). No significant potentiation was detected in the presence of both the mGluR1 and the mGluR5 antagonist (DHPG plus MPEP plus CPCCOEt, $9 \pm 4 \% ; n=5$; $p>0.05)$ (Fig. 3D).
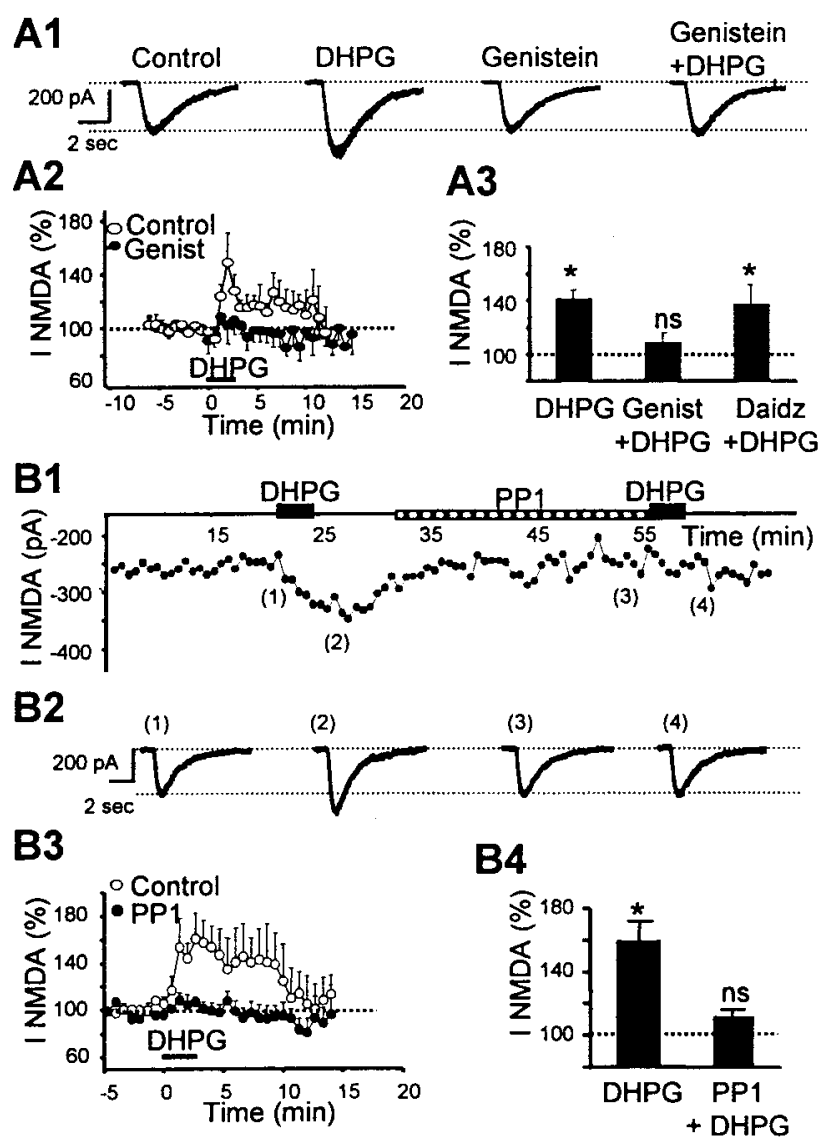

Figure 2. Src is required for mGluR-mediated potentiation of NMDA current. $A$, Genistein, a broad-spectrum blocker of tyrosine kinase, inhibits DHPG-induced potentiation of NMDA current. A1, Single traces from the same neuron show that the increase in NMDA current amplitude induced by DHPG $(10 \mu \mathrm{M})$ is prevented in the presence of genistein (30 $\mu \mathrm{M}$ for $15 \mathrm{~min}$ ). Genistein alone does not alter NMDA current. A2, Averaged results from five cells comparing the effect on NMDA current of $10 \mu \mathrm{M}$ DHPG alone (open circles) and in the presence of genistein (filled circles). A3, Potentiation of NMDA current by $10 \mu \mathrm{M}$ DHPG is inhibited by genistein ( $30 \mu \mathrm{M} ; n=5)$ but not by its inactive analog daidzein $(30 \mu \mathrm{M} ; n=5)$; ${ }^{*} p<0.05 . B$, PP1, a specific inhibitor of Src kinase, inhibits the DHPG-induced potentiation of NMDA current. B1, Time course of action on peak NMDA current of DHPG (10 $\mu \mathrm{M}$ for 2 min) before and after a 15 min application of $25 \mu \mathrm{M}$ PP1 in a representative cell. PP1 alone does not alter NMDA current. B2, Single NMDA current traces from this cell. B3, Averaged results from five cells comparing the effect on NMDA current of DHPG before (open circles) and after (filled circles) PP1 incubation. B4, Pooled data comparing responses to DHPG alone and DHPG in the presence of PP1 $(n=5)$; ${ }^{*} p<0.05$. Dotted lines indicate baseline or control responses.

\section{G-protein blockade does not prevent mGluR-mediated potentiation of NMDA current}

Stimulation of mGluRs can activate Src via a G-proteinindependent signaling pathway in CA3 pyramidal cells (Heuss et al., 1999). To determine whether this mechanism contributes to the potentiation of NMDA currents, we examined the response to mGluR activation in cells in which G-protein activity was blocked by intracellular perfusion of GDP $\beta S$ ( $1 \mathrm{mM})$. To establish effective inhibition of G-protein function by GDP $\beta S$, we waited until the postsynaptic response to the bath-applied $\mathrm{GABA}_{\mathrm{B}}$ agonist baclofen $(20 \mu \mathrm{M}$ for $1 \mathrm{~min})$ was blocked fully in each cell before testing the effects of mGluR activation $(124 \pm 30 \mathrm{pA}$ just after beginning whole-cell recording vs $5 \pm 5$ pA after $20-40$ min of 

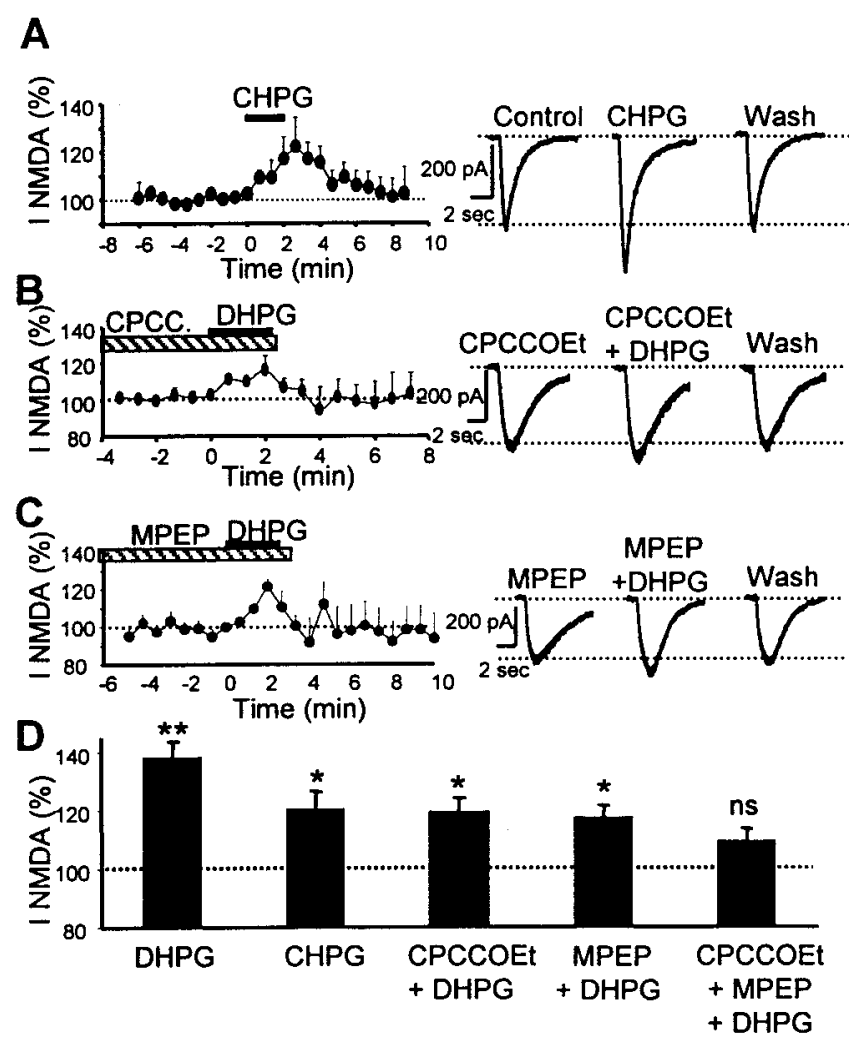

Figure 3. Activation of either mGluR5 or mGluR1 potentiates NMDA current. $A$, Average time course of NMDA current potentiation induced by the mGluR5-specific agonist CHPG $(500 \mu \mathrm{M}$ for $2 \mathrm{~min} ; n=8)$. Representative traces from one cell are shown (right). B, Alternatively, mGluR5 was stimulated selectively by the application of DHPG (10 $\mu \mathrm{M}$ for $2 \mathrm{~min}$ ) in the presence of a saturating concentration of the mGluR1 antagonist CPCCOEt (50 $\mu \mathrm{M}$ for $10 \mathrm{~min} ; n=6)$. Average time course (left) and representative traces (right) are shown. $C$, mGluR1 was stimulated selectively by the application of DHPG (10 $\mu \mathrm{M}$ for $2 \mathrm{~min})$ in the presence of a saturating concentration of the mGluR5 antagonist MPEP $(10 \mu \mathrm{M}$ for $10 \mathrm{~min})$. Average time course (left) and representative traces (right) are shown. $D$, Pooled data indicate that, although the selective activation of either mGluR5 (CHPG, $n=8$; CPCCOEt plus DHPG, $n=$ 4) or mGluR1 (MPEP plus DHPG, $n=5$ ) significantly potentiates NMDA current, greater potentiation is observed with the coactivation of mGluR1 and mGluR5 (DHPG, $n=23$ ). No significant potentiation is detected in the presence of both mGluR1 and mGluR5 antagonists (CPCCOEt plus MPEP plus DHPG, $n=5$ ); ${ }^{*} p<0.05$ and ${ }^{* *} p<0.01$.

GDP $\beta$ S diffusion; $n=6 ; p<0.001$ ) (Fig. 4A). In addition, GDP $\beta S$ prevented the increase in input resistance induced by DHPG $(1 \pm 2 \%, n=6$ vs $15 \pm 4 \%$ in control, $n=19 ; p<0.05$; data not shown), further indicating that the class of G-protein associated with group I mGluRs was blocked effectively. Under conditions of G-protein blockade, DHPG (10 $\mu \mathrm{M}$ for $2 \mathrm{~min})$ still potentiated NMDA current $(29 \pm 5 \%, n=6 ; p<0.01$ vs baseline) (Fig. 4B). Moreover, this G-protein-independent increase in NMDA current was blocked by the Src inhibitor PP1 (25 $\mu \mathrm{M}$ for $20 \mathrm{~min} ;-1 \pm 4 \%, n=5 ; p>0.05$ vs baseline) (Fig. $4 F$ ).

\section{mGluR1, but not mGluR5, can potentiate NMDA current via a G-protein-independent mechanism}

To assess whether both group I mGluRs can signal via G-proteinindependent mechanisms, we repeated the above experiments but selectively stimulated either mGluR1 or mGluR5. In GDP $\beta$ Streated cells in which baclofen no longer induced a response, the application of the mGluR5-specific agonist CHPG (500 $\mu \mathrm{M}$ for 2

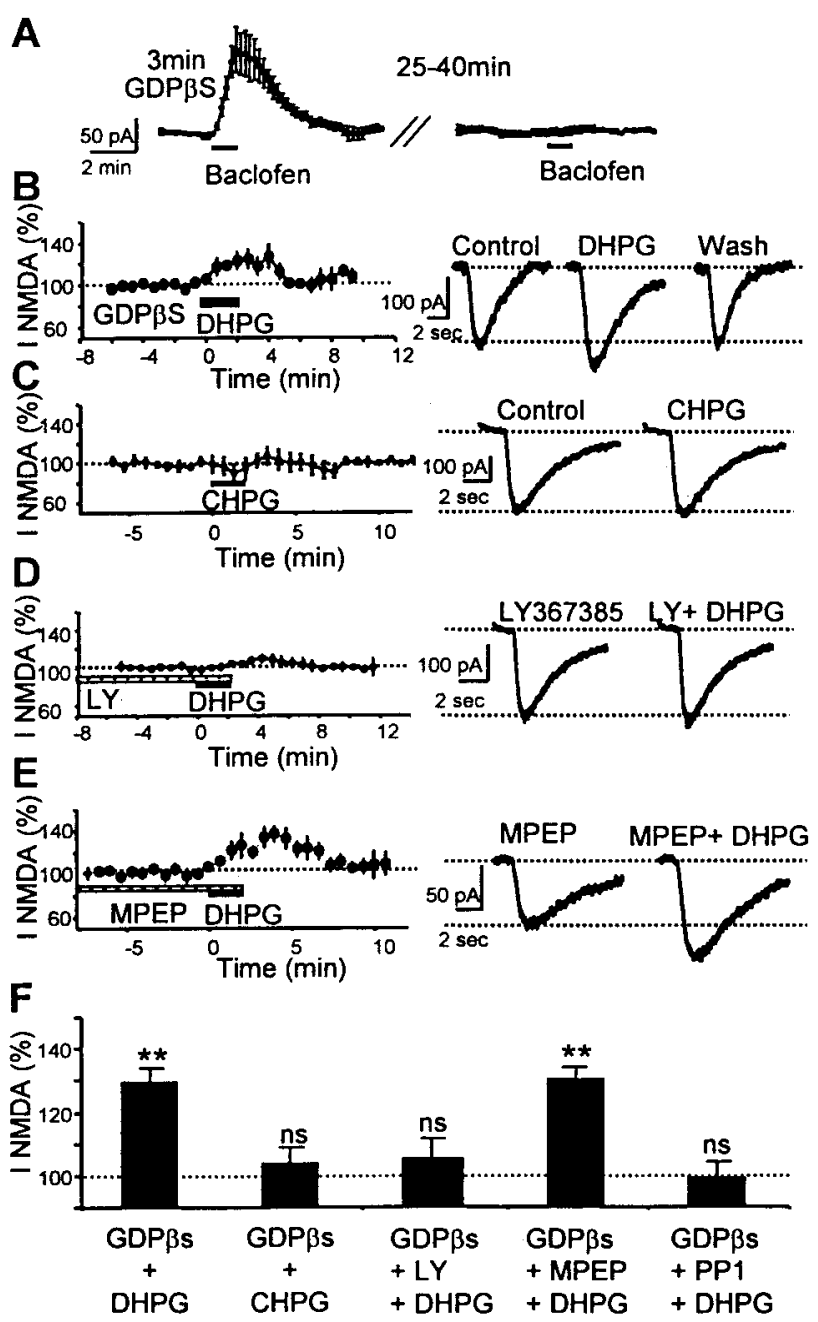

Figure 4. G-protein-independent potentiation of NMDA current is mediated by mGluR1 but not by mGluR5. $A$, Within 3 min of establishing the whole-cell configuration with a patch pipette containing $1 \mathrm{~mm}$ GDP $\beta S$, the application of baclofen $(20 \mu \mathrm{M}$ for $1 \mathrm{~min})$ induces an outward $\mathrm{K}^{+}$ current. Having allowed 20-40 min for GDP $\beta S$ to diff use into the cell, reapplication of baclofen no longer produces a response, indicating a blockade of the G-protein function $(n=6)$. $B$, After the baclofen response is blocked completely, DHPG (10 $\mu \mathrm{M}$ for $2 \mathrm{~min})$ still potentiates NMDA current $(n=6)$. Representative traces from one cell are shown on the right. $C$, Average time course of NMDA current in six GDP $\beta$ S-treated cells exposed to the mGluR5-specific agonist CHPG (500 $\mu \mathrm{M}$ for $2 \mathrm{~min})$, indicating a lack of potentiation. Representative traces from one cell are shown on the right. $D$, Average time course of NMDA current in five GDP $\beta$ S-treated cells in which mGluR5 activation is obtained by applying DHPG (10 $\mu \mathrm{M}$ for $2 \mathrm{~min})$ in the presence of a saturating concentration of the mGluR1 antagonist LY367385 (50 $\mu \mathrm{M}$ for $10 \mathrm{~min})$, again showing that NMDA current is not potentiated. Representative traces from one cell are shown on the right. $E$, Average time course of NMDA current in five GDP $\beta$ S-treated cells in which mGluR1 is activated selectively by applying DHPG (10 $\mu \mathrm{M}$ for $2 \mathrm{~min})$ in the presence of a saturating concentration of the mGluR5 antagonist MPEP (10 $\mu \mathrm{M}$ for $10 \mathrm{~min})$, showing marked potentiation. Representative traces from one cell are shown on the right. $F$, Pooled data for GDP $\beta$ S-treated cells showing that the activation of mGluR1 plus mGluR5 with DHPG $(n=6)$ significantly potentiates NMDA current. Selective activation of mGluR5 with CHPG $(n=6)$ or LY367385 plus DHPG $(n=5)$ does not potentiate NMDA current, whereas the selective activation of mGluR1 (MPEP plus DHPG, $n=5$ ) potentiates NMDA current to a similar degree, as does the coactivation of mGluR1 plus mGluR5 with DHPG. DHPG-induced potentiation is blocked completely by the Src inhibitor PP1 (25 $\mu \mathrm{M}$ for $20 \mathrm{~min} ; n=5)$; $* * p<0.01$. 


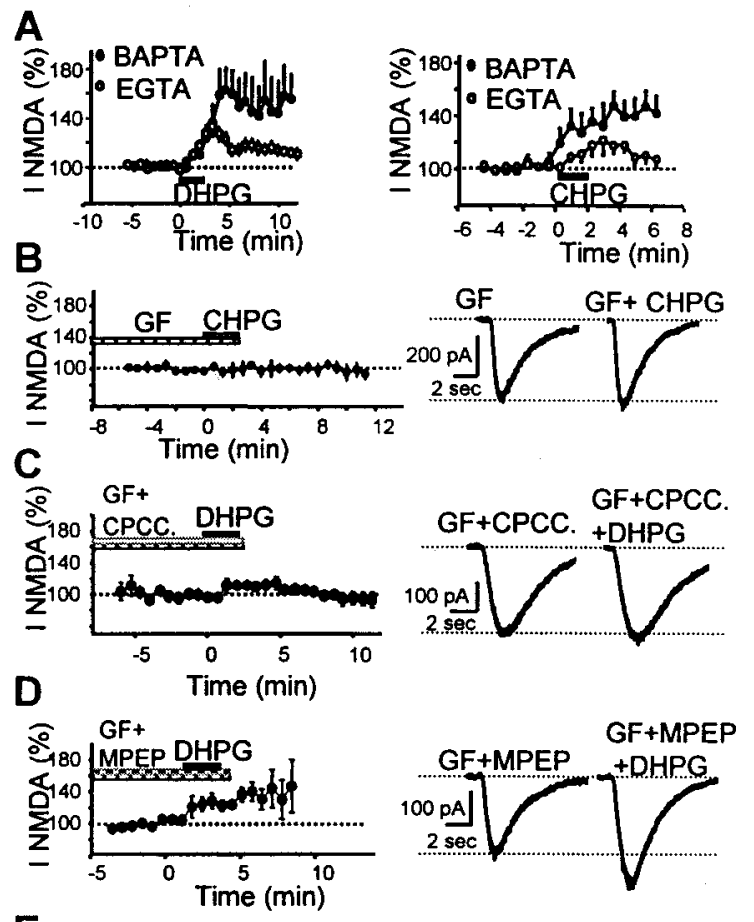

E
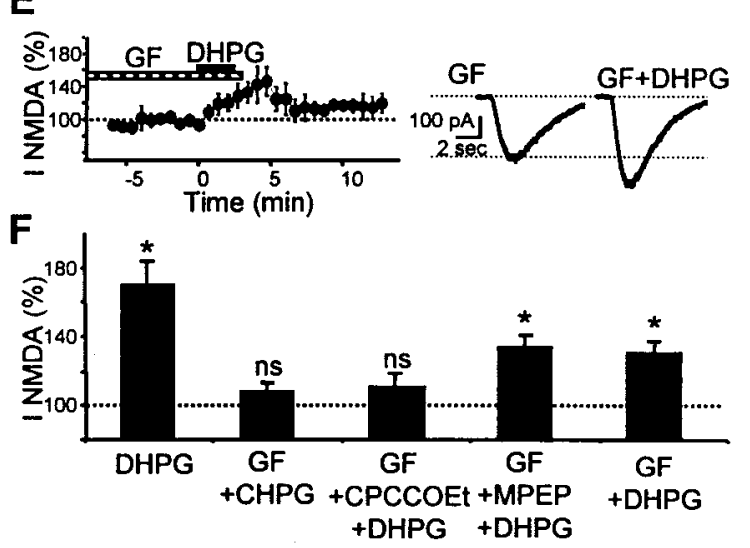

Figure 5. Blocking PKC activation prevents NMDA current potentiation by mGluR5 but not by mGluR1. For all experiments with the PKC inhibitor, GDP $\beta$ S was not present and BAPTA $(10 \mathrm{mM})$ was used in the pipette solution to minimize the $\mathrm{Ca}^{2+}$-dependent inhibition of NMDA current. A, Left, Average time course of NMDA current potentiation induced by DHPG (10 $\mu \mathrm{M}$ for 2 min) either with EGTA (open circles; 10 $\mathrm{mM} ; n=23$ ) or with BAPTA ( filled circles; $10 \mathrm{mM} ; n=6$ ) in the recording pipette. A, Right, Data using the same protocol but with the mGluR5specific agonist CHPG (500 $\mu \mathrm{M}$ for $2 \mathrm{~min})$ either with EGTA $(10 \mathrm{~mm} ; n=$ $8)$ or with BAPTA $(10 \mathrm{~mm} ; n=7)$ in the recording pipette. $B$. Inhibition of PKC with the specific inhibitor GF109203X ( $2 \mu \mathrm{M}$ for $20 \mathrm{~min}$ ) prevents NMDA current potentiation in response to the mGluR5-specific agonist CHPG (500 $\mu \mathrm{M}$ for $2 \mathrm{~min} ; n=6)$. Representative traces from one cell are shown on the right. $C$, Similarly, inhibition of PKC prevents NMDA current potentiation in response to mGluR5 activation by the application of DHPG $(10 \mu \mathrm{M}$ for $2 \mathrm{~min} ; n=4)$ in the presence of a saturating concentration of the mGluR1 antagonist CPCCOEt (50 $\mu \mathrm{M}$ for $10 \mathrm{~min})$. Representative traces from one cell are shown on the right. $D$, In contrast, the selective activation of mGluR1 by the application of DHPG $(10 \mu \mathrm{M}$ for $2 \mathrm{~min}$ ) in the presence of a saturating concentration of the mGluR5 antagonist MPEP (10 $\mu \mathrm{M}$ for $10 \mathrm{~min})$ still potentiates NMDA current under conditions in which PKC is blocked $(n=5)$. Representative traces from one cell are shown on the right. E, Average time course of NMDA current potentiation induced by DHPG $(10 \mu \mathrm{M}$ for $2 \mathrm{~min} ; n=5)$ in the presence of the PKC inhibitor. Representative traces from one cell are shown on the right. $F$, Pooled data showing that, after the inhibition of PKC, the selective activation of mGluR5 (CHPG, $n=6$; or LY367385 min) failed to potentiate NMDA current $(3 \pm 5 \%, n=6 ; p>0.05$ vs baseline) (Fig. $4 C$ ). The same lack of effect was observed when mGluR5 was stimulated by applying DHPG (10 $\mu \mathrm{M}$ for $2 \mathrm{~min})$ in the presence of a saturating concentration of the mGluR1 antagonist LY367385 (50 $\mu \mathrm{M}$ for $10 \mathrm{~min})(5 \pm 6 \%, n=5 ; p>0.05 \mathrm{vs}$ baseline) (Fig. $4 D$ ). Blocking G-protein activity did not, however, prevent the potentiation of NMDA current by selective activation of mGluR1 (10 $\mu \mathrm{M}$ DHPG for $2 \mathrm{~min}$ in the presence of a saturating concentration of the mGluR5 antagonist $10 \mu \mathrm{M}$ MPEP for $10 \mathrm{~min} ; 29 \pm 3 \%, n=5 ; p<0.01$ vs baseline and $p>0.05$ vs GDP $\beta$ S plus DHPG alone) (Fig. $4 E$ ). Thus the potentiation of NMDA current by mGluR5, but not by mGluR1, absolutely requires G-protein activation. The potentiation of NMDA current induced by selective mGluR1 activation after G-protein blockade was significantly greater than that induced by mGluR1 activation in control $[18 \pm 4 \%, n=5$ in presence of GTP (Fig. 3) compared with $29 \pm 3 \%, n=5$ in presence of GDP $\beta$ S; $p<0.05$ (Fig. 4)], suggesting that a G-protein-dependent process also may antagonize mGluR-mediated potentiation of NMDA receptor function (see Discussion).

\section{Role of the PLC $\rightarrow$ DAG $\rightarrow$ PKC pathway in mGluR-mediated potentiation of NMDA current}

Having established that mGluR1 activation can potentiate NMDA current via a G-protein-independent pathway, we addressed the mechanism underlying G-protein-dependent potentiation via mGluR5. Previous work in CA1 pyramidal cells has demonstrated that the G-protein-dependent activation of a pathway involving the sequential activation of PLC $\rightarrow$ DAG $\rightarrow$ PKC $\rightarrow$ Pyk $2 / C A K \beta \rightarrow$ Src induces tyrosine phosphorylation of NMDA receptors, resulting in their functional potentiation (Lu et al., 1999; Huang et al., 2001). To obtain evidence for the activation of a similar pathway in CA3 cells, we examined the effects of specifically blocking PKC, but without blocking G-proteins. To facilitate the interpretation of our results involving the PLC $\rightarrow$ DAG $\rightarrow$ PKC pathway, we tried to minimize the contribution from the $\mathrm{PLC} \rightarrow \mathrm{IP}_{3} \rightarrow \mathrm{Ca}^{2+}$ pathway by performing all of the subsequent experiments with BAPTA (10 $\mathrm{mM}$ ) in the recording pipette solution (Adler et al., 1991). Intracellular BAPTA resulted in significantly greater potentiation of NMDA current in response to DHPG (10 $\mu \mathrm{M}$ for $2 \mathrm{~min})$ than with EGTA as the intracellular $\mathrm{Ca}^{2+}$ buffer $(73 \pm 13 \%, n=6 ; p<0.05$ vs EGTA solution) (Fig. $5 A$ ). Furthermore, the greater potentiation with intracellular BAPTA was more apparent with the activation of mGluR1 than mGluR5 [10 $\mu \mathrm{M}$ MPEP plus $10 \mu \mathrm{M}$ DHPG potentiated by $41 \pm 13 \%, n=5$ with BAPTA vs $18 \pm 4 \%, n=5$ with EGTA; $p<0.05$; (data not shown); CHPG potentiated by $39 \pm 10 \%, n=7$ with BAPTA vs $20 \pm 5 \%, n=8$ with EGTA; $p>0.05$ (Fig. 5A)].

The addition of the PKC inhibitor GF109203X ( $2 \mu \mathrm{M}$ for 20 $\min )$ to the bath prevented NMDA current potentiation in response to selective mGluR5 activation $(7 \pm 6 \%, n=6 ; p>0.05$ vs baseline for CHPG $500 \mu \mathrm{M} ; 10 \pm 8 \%, n=4 ; p>0.05$ vs baseline for $10 \mu \mathrm{M}$ DHPG plus $50 \mu \mathrm{M} \mathrm{CPCCOEt)} \mathrm{(Fig.} 5 B, C$ ). In contrast, potentiation of NMDA current induced by the selective activation of mGluR1 (10 $\mu \mathrm{M}$ DHPG for 2 min plus $10 \mu \mathrm{M}$ MPEP

plus DHPG, $n=4$ ) does not potentiate NMDA current, whereas the selective activation of mGluR1 (MPEP plus DHPG, $n=5$ ) induces a potentiation comparable with that seen with the coactivation of mGluR1 plus mGluR5. Note that NMDA current potentiation induced by the coactivation of mGluR1 plus mGluR5 after PKC inhibition is reduced but still significant $(n=5) ; * p<0.05$. 
for $10 \mathrm{~min}$ ) was not blocked after PKC inhibition with GF109203X (33 $\pm 6 \%, n=5 ; p<0.05$ vs baseline) (Fig. $5 D)$. We observed that, after the selective activation of mGluR1 (DHPG plus MPEP) in presence of BAPTA, the maximal degree of potentiation with or without GF109203X was not significantly different $(p>0.05)$.

Similarly, the potentiation of NMDA current with the activation of mGluR1 plus mGluR5 with DHPG (10 $\mu \mathrm{M}$ for $2 \mathrm{~min})$ persisted in the presence of GF109203X (10 $\mu \mathrm{M}$ for $2 \mathrm{~min} ; 30 \pm$ $7 \%, n=5 ; p<0.05$ vs baseline) (Fig. $5 E$ ). Control experiments showed that GF109203X completely blocked the potentiation of NMDA currents induced by the bath application of PMA (250 nM for $10 \mathrm{~min})$, a PKC activator $(28 \pm 3 \%, n=5, p<0.05$ vs baseline for PMA alone; $5 \pm 3 \%, n=4, p>0.05$ vs baseline for PMA plus GF109203X; data not shown).

\section{DISCUSSION}

Our results show that in CA3 pyramidal cells the activation of either postsynaptic mGluR1 or mGluR5 leads to potentiation of NMDA receptor current via a Src-dependent mechanism. The mGluR5-dependent potentiation of NMDA current is mediated exclusively via G-protein- and PKC-dependent activation of Src, whereas mGluR1-dependent potentiation can occur via G-protein- and PKC-independent activation of Src. The upregulation of NMDA responses by Src is well established, involving the phosphorylation of receptor tyrosine residues, which increases channel open probability (Salter, 1998; Ali and Salter, 2001). This mode of NMDA receptor enhancement can be triggered by muscarinic or lysophosphatidic acid receptors (Gprotein-coupled receptors) or by receptors for leptin, EphB, or BDNF (Levine et al., 1998; Lu et al., 1999; Shanley et al., 2001; Takasu et al., 2002). Because mGluRs also have been shown to activate Src (Fiore et al., 1993; Siciliano et al., 1994; Heuss et al., 1999; Boxall, 2000; Peavy et al., 2001), the potentiation of NMDA responses via this mechanism was not unexpected.

We have found that either mGluR1 or mGluR5 can mediate NMDA current enhancement in CA3 pyramidal cells. In contrast, studies in various other brain areas have identified mGluR5 as uniquely responsible for NMDA receptor potentiation (Doherty et al., 1997, 2000; Jia et al., 1998; Awad et al., 2000; Mannaioni et al., 2001; Pisani et al., 2001). We interpret these findings as a reflection of low mGluR1 expression, the presence of alternative splice variants of mGluRs, or of a low incidence of colocalization of mGluR1 and NMDA receptors in these other cell types. In CA3 pyramidal cells immunohistochemical studies have revealed postsynaptic localization of both mGluR1 and mGluR5 (Shigemoto et al., 1997), and in Xenopus oocytes coexpressing mGluR1 and NMDA receptors metabotropic agonists do potentiate NMDA responses (Lan et al., 2001; Skeberdis et al., 2001). A recent study now has revealed mGluR1-mediated potentiation of NMDA current in cortical neurons (Heidinger et al., 2002).

Our results suggest that synaptic NMDA currents are potentiated by activation of group I mGluRs. As shown previously, however, experiments to test this hypothesis are confounded by the strong presynaptic depression of neurotransmitter release that follows the activation of group I mGluRs (Gereau and Conn, 1995; Manzoni and Bockaert, 1995; Rodriguez-Moreno et al., 1998; Fitzjohn et al., 2001; Mannaioni et al., 2001; Watabe et al., 2002).

\section{Signal transduction pathways}

Earlier investigations into the transduction mechanisms underlying mGluR-mediated upregulation of NMDA receptor function have focused primarily on the possible involvement of the PLC/ PKC pathway. Approximately one-half of these studies concluded that PKC activation is required for potentiation (Aniksztejn et al., 1991; Kelso et al., 1992; Pisani et al., 1997; Ugolini et al., 1997; Skeberdis et al., 2001), whereas others found no indication for PKC involvement (Harvey and Collingridge, 1993; Kinney and Slater, 1993; Rahman and Neuman, 1996; Holohean et al., 1999). Our data provide a reasonable resolution for this discrepancy by showing that both a PLC/PKC-dependent pathway as well as a G-protein- and PKC-independent pathway can lead to Srcmediated potentiation of NMDA current. Our results are consistent with those from a recent study suggesting that mGluR5 signals via PKC to enhance NMDA-mediated responses (Jia et al., 1998). A detailed characterization of this transduction pathway in CA1 pyramidal cells has provided the following activation sequence: G-protein $\rightarrow$ PLC $\rightarrow$ DAG $\rightarrow$ PKC $\rightarrow$ Pyk $2 / \mathrm{CAK} \beta \rightarrow$ $\mathrm{Src} \rightarrow$ NMDA receptors (Lu et al., 1999; Huang et al., 2001).

Signal transduction via mGluR1 appears to be more complex. We have shown previously in CA3 pyramidal cells that the same population of synaptic mGluR1s, activated by the stimulation of mossy fibers, signals via divergent pathways, one G-proteindependent and the other G-protein-independent (Heuss et al., 1999). Although both pathways could be involved in the potentiation of NMDA current by mGluR1, our data show that the G-protein-independent mechanism predominates. Thus both G-protein inhibition as well as PKC blockade (see also Heidinger et al., 2002) did not prevent mGluR1-mediated potentiation.

The mechanism underlying the G-protein-independent activation of Src by mGluR1 is not known. In other systems G-proteinindependent signaling by metabotropic receptors can initiate the binding of the adapter protein arrestin to the activated receptor, resulting in the recruitment of Src (Hall et al., 1999). Arrestin has been shown to bind to mGluR1a (Dale et al., 2001; Mundell et al., 2001), but whether this association leads to Src activation remains to be determined.

\section{Modulation by $\mathrm{Ca}^{2+}$}

An unexpected observation in our study was that selective activation of mGluR1 resulted in significantly greater potentiation of NMDA current after G-protein blockade than under control conditions. Thus the activation of mGluRs appears to induce a concomitant G-protein-dependent inhibition of NMDA current. Both mGluR1 and mGluR5 mediate a G-protein-dependent release of intracellular calcium stores (Valenti et al., 2002). Moreover, NMDA receptor function is inhibited by a rise in intracellular calcium (Mayer and Westbrook, 1985; Legendre et al., 1993; Lieberman and Mody, 1994; Rosenmund et al., 1995). Hence it is likely that the G-protein-dependent release of intracellular calcium via mGluR activation will depress NMDA responses. Our experimental protocol leads to an increase in intracellular $\mathrm{Ca}^{2+}$ concentration via two mechanisms: (1) $\mathrm{Ca}^{2+}$ influx through the repetitively activated NMDA receptor channels and (2) $\mathrm{Ca}^{2+}$ release from $\mathrm{IP}_{3}$-sensitive stores in response to G-proteindependent activation of PLC via mGluR stimulation. Further evidence for our hypothesis is provided by the observation that increasing the DHPG concentration to $50 \mu \mathrm{M}(3 \mathrm{~min})$ in the presence of $3 \mathrm{~mm}$ extracellular calcium with low intracellular calcium buffering suppresses the potentiation (data not shown), whereas accelerating intracellular $\mathrm{Ca}^{2+}$ buffering by including 
BAPTA in the recording pipette substantially enhances the potentiation of NMDA current and delays recovery of mGluRinduced potentiation (Fig. 5A). Small differences in experimental conditions affecting $\mathrm{Ca}^{2+}$ homeostasis therefore may account for the conflicting observations with respect to mGluR-mediated effects on NMDA receptor function. Indeed, studies in which relatively high levels of intracellular $\mathrm{Ca}^{2+}$ would be expected, either because of low $\mathrm{Ca}^{2+}$ buffering or because of increased $\mathrm{IP}_{3}$ production induced by high mGluR agonist concentrations, report mGluR-mediated reduction of NMDA current (Wang et al., 1998; Zhong et al., 2000; Snyder et al., 2001). Similarly, in our preparation high concentrations of DHPG (100 $\mu \mathrm{M}$; our unpublished data) depressed NMDA current. However, an increase in intracellular $\mathrm{Ca}^{2+}$ also will enhance PKC activity (Nishizuka, 1988), which would potentiate NMDA responses via the Src pathway. The net result of $\mathrm{Ca}^{2+}$ on NMDA responses is thus difficult to predict and is likely to depend on the extent and compartmental localization of the intracellular $\mathrm{Ca}^{2+}$ rise. In addition to a $\mathrm{Ca}^{2+}$-dependent reduction in NMDA current, it should be pointed out that direct membrane-delimited inhibition via G-proteins also may lead to NMDA current inhibition ( $\mathrm{Yu}$ et al., 1997).

\section{Conclusion}

Why should a neuron possess two parallel pathways to modulate NMDA receptor function, one G-protein-dependent and one G-protein-independent? G-protein function is controlled through a complex interplay of regulatory molecules, permitting both enhanced transduction as well as functional uncoupling of G-proteins from cognate receptors (Alagarsamy et al., 2001). A receptor system, which includes the added option of G-proteinindependent signaling, will provide a cell with greater flexibility in responding to stimuli under a wide range of physiological and pathophysiological conditions. Not only could certain responses be maintained when G-protein-dependent pathways have been shut off, but more focused activation of specific proteins would be ensured. For example, in the case of mGluRs selective G-proteinindependent signaling would allow for the activation of Src without the concomitant triggering of transduction cascades associated with PLC, PKC, or $\mathrm{IP}_{3}$.

Our finding that the coactivation of mGluR1 and mGluR5 induced larger responses than the activation of either subtype alone suggests that the two receptor subtypes target different populations of NMDA receptors (Salter, 2001). Thus mGluR1 receptors, which in CA3 cells can be activated synaptically (Heuss et al., 1999), may modulate synaptic NMDA receptors, whereas mGluR5 receptors in these cells might be activated primarily by glutamate spillover and preferentially target extrasynaptic NMDA receptors.

\section{REFERENCES}

Adler EM, Augustine GJ, Duffy SN, Charlton MP (1991) Alien intracellular calcium chelators attenuate neurotransmitter release at the squid giant synapse. J Neurosci 11:1496-1507.

Alagarsamy S, Sorensen SD, Conn PJ (2001) Coordinate regulation of metabotropic glutamate receptors. Curr Opin Neurobiol 11:357-362.

Ali DW, Salter MW (2001) NMDA receptor regulation by Src kinase signaling in excitatory synaptic transmission and plasticity. Curr Opin Neurobiol 11:336-342.

Aniksztejn L, Bregestovski P, Ben-Ari Y (1991) Selective activation of quisqualate metabotropic receptor potentiates NMDA but not AMPA responses. Eur J Pharmacol 205:327-328.

Anwyl R (1999) Metabotropic glutamate receptors: electrophysiological properties and role in plasticity. Brain Res Brain Res Rev 29:83-120.

Awad H, Hubert GW, Smith Y, Levey AI, Conn PJ (2000) Activation of metabotropic glutamate receptor 5 has direct excitatory effects and potentiates NMDA receptor currents in neurons of the subthalamic nucleus. J Neurosci 20:7871-7879.

Baude A, Nusser Z, Roberts JD, Mulvihill E, McIlhinney RA, Somogyi $\mathrm{P}$ (1993) The metabotropic glutamate receptor (mGluR1 $\alpha$ ) is concentrated at perisynaptic membrane of neuronal subpopulations as detected by immunogold reaction. Neuron 4:771-787.

Bleakman D, Rusin KI, Chard PS, Glaum SR, Miller RJ (1992) Metabotropic glutamate receptors potentiate ionotropic glutamate responses in the rat dorsal horn. Mol Pharmacol 42:192-196.

Boxall AR (2000) GABAergic mIPSCs in rat cerebellar Purkinje cells are modulated by TrkB and mGluR1-mediated stimulation of Src. J Physiol (Lond) 524:677-684.

Conn PJ, Pin JP (1997) Pharmacology and functions of metabotropic glutamate receptors. Annu Rev Pharmacol Toxicol 37:205-237.

Dale LB, Bhattacharya M, Seachrist JL, Anborgh PH, Ferguson SS (2001) Agonist-stimulated and tonic internalization of metabotropic glutamate receptor 1a in human embryonic kidney 293 cells: agoniststimulated endocytosis is $\beta$-arrestin1 isoform-specific. Mol Pharmacol 60:1243-1253.

Doherty AJ, Palmer MJ, Henley JM, Collingridge GL, Jane DE (1997) (RS)-2-chloro-5-hydroxyphenylglycine (CHPG) activates mGlu5, but no mGlu1, receptors expressed in CHO cells and potentiates NMDA responses in the hippocampus. Neuropharmacology 36:265-267.

Doherty AJ, Palmer MJ, Bortolotto ZA, Hargreaves A, Kingston AE, Ornstein PL, Schoepp DD, Lodge D, Collingridge GL (2000) A novel, competitive mGlu5 receptor antagonist (LY344545) blocks DHPGinduced potentiation of NMDA responses, but not the induction of LTP, in rat hippocampal slices. Br J Pharmacol 131:239-244.

Fiore RS, Murphy TH, Sanghera JS, Pelech SL, Baraban JM (1993) Activation of p42 mitogen-activated protein kinase by glutamate receptor stimulation in rat primary cortical cultures. J Neurochem 61:1626-1633

Fitzjohn SM, Palmer MJ, May JE, Neeson A, Morris SA, Collingridge GL (2001) Characterization of long-term depression induced by metabotropic glutamate receptor activation in the rat hippocampus in vitro. J Physiol (Lond) 537:421-430.

Gähwiler BH, Thompson SM, McKinney RA, Debanne D, Robertson RT (1998) Culturing nerve cells. In: Organotypic slice cultures of neural tissue (Banker G, Goslin K, eds), pp 461-498 Cambridge, MA: MIT.

Gereau RW, Conn PJ (1995) Multiple presynaptic metabotropic glutamate receptors modulate excitatory and inhibitory synaptic transmission in hippocampal area CA1. J Neurosci 15:6879-6889.

Guérineau NC, Gähwiler BH, Gerber U (1994) Reduction of resting K ${ }^{+}$ current by metabotropic glutamate and muscarinic receptors in rat CA3 cells: mediation by G-proteins. J Physiol (Lond) 474:27-33.

Hall RA, Premont RT, Lefkowitz RJ (1999) Heptahelical receptor signaling: beyond the G-protein paradigm. J Cell Biol 145:927-932.

Harvey J, Collingridge GL (1993) Signal transduction pathways involved in the acute potentiation of NMDA responses by $1 S, 3 R$-ACPD in rat hippocampal slices. Br J Pharmacol 109:1085-1090.

Heidinger V, Manzerra P, Wang XQ, Strasser U, Yu SP, Choi DW, Behrens MM (2002) Metabotropic glutamate receptor 1-induced upregulation of NMDA receptor current: mediation through the Pyk2/ Src-family kinase pathway in cortical neurons. J Neurosci 22:5452-5461.

Heuss C, Scanziani M, Gähwiler BH, Gerber U (1999) G-proteinindependent signaling mediated by metabotropic glutamate receptors. Nat Neurosci 2:1070-1077.

Holohean AM, Hackman JC, Davidoff RA (1999) Mechanisms involved in the metabotropic glutamate receptor-enhancement of NMDAmediated motoneurone responses in frog spinal cord. Br J Pharmacol 126:333-341.

Huang Y, Lu W, Ali DW, Pelkey KA, Pitcher GM, Lu YM, Aoto H, Roder JC, Sasaki T, Salter MW, MacDonald JF (2001) CAK $\beta /$ Pyk2 kinase is a signaling link for induction of long-term potentiation in CA1 hippocampus. Neuron 29:485-496.

Jia Z, Lu Y, Henderson J, Taverna F, Romano C, Abramow-Newerly W, Wojtowicz JM, Roder J (1998) Selective abolition of the NMDA component of long-term potentiation in mice lacking mGluR5. Learn Mem 5:331-343.

Kelso SR, Nelson TE, Leonard JP (1992) Protein kinase C-mediated enhancement of NMDA currents by metabotropic glutamate receptors in Xenopus oocytes. J Physiol (Lond) 449:705-718.

Kinney GA, Slater NT (1993) Potentiation of NMDA receptormediated transmission in turtle cerebellar granule cells by activation of metabotropic glutamate receptors. J Neurophysiol 69:585-594.

Lan JY, Skeberdis VA, Jove T, Zheng X, Bennett MV, Zukin RS (2001) Activation of metabotropic glutamate receptor 1 accelerates NMDA receptor trafficking. J Neurosci 21:6058-6068.

Legendre P, Rosenmund C, Westbrook GL (1993) Inactivation of NMDA channels in cultured hippocampal neurons by intracellular calcium. J Neurosci 13:674-684.

Levine ES, Crozier RA, Black IB, Plummer MR (1998) Brain-derived neurotrophic factor modulates hippocampal synaptic transmission by 
increasing $N$-methyl-D-aspartic acid receptor activity. Proc Natl Acad Sci USA 95:10235-10239.

Lieberman DN, Mody I (1994) Regulation of NMDA channel function by endogenous $\mathrm{Ca}^{2+}$-dependent phosphatase. Nature 369:235-239.

Lu WY, Xiong ZG, Lei S, Orser BA, Dudek E, Browning MD, MacDonald JF (1999) G-protein-coupled receptors act via protein kinase $\mathrm{C}$ and Src to regulate NMDA receptors. Nat Neurosci 2:331-338.

Lujan R, Nusser Z, Roberts JD, Shigemoto R, Somogyi P (1996) Perisynaptic location of metabotropic glutamate receptors mGluR1 and mGluR5 on dendrites and dendritic spines in the rat hippocampus. Eur J Neurosci 8:1488-1500.

Lujan R, Roberts JD, Shigemoto R, Ohishi H, Somogyi P (1997) Differential plasma membrane distribution of metabotropic glutamate receptors mGluR1 $\alpha$, mGluR2, and mGluR5, relative to neurotransmitter release sites. J Chem Neuroanat 13:219-241.

Mannaioni G, Marino MJ, Valenti O, Traynelis SF, Conn PJ (2001) Metabotropic glutamate receptors 1 and 5 differentially regulate CA1 pyramidal cell function. J Neurosci 21:5925-5934.

Manzoni O, Bockaert J (1995) Metabotropic glutamate receptors inhibiting excitatory synapses in the CA1 area of rat hippocampus. Eur J Neurosci 7:2518-2523.

Mayer ML, Westbrook GL (1985) The action of $N$-methyl-D-aspartic acid on mouse spinal neurones in culture. J Physiol (Lond) 361:65-90.

McCool BA, Pin JP, Brust PF, Harpold MM, Lovinger DM (1996) Functional coupling of rat group II metabotropic glutamate receptors to an $\omega$-conotoxin GVIA-sensitive calcium channel in human embryonic kidney 293 cells. Mol Pharmacol 50:912-922.

Mundell SJ, Matharu AL, Pula G, Roberts PJ, Kelly E (2001) Agonistinduced internalization of the metabotropic glutamate receptor $1 \mathrm{a}$ is arrestin- and dynamin-dependent. J Neurochem 78:546-551.

Nishizuka Y (1988) The molecular heterogeneity of protein kinase C and its implications for cellular regulation. Nature 334:661-665.

Peavy RD, Chang MS, Sanders-Bush E, Conn PJ (2001) Metabotropic glutamate receptor 5-induced phosphorylation of extracellular signalregulated kinase in astrocytes depends on transactivation of the epidermal growth factor receptor. J Neurosci 21:9619-9628.

Pisani A, Calabresi P, Centonze D, Bernardi G (1997) Enhancement of NMDA responses by group I metabotropic glutamate receptor activation in striatal neurons. Br J Pharmacol 120:1007-1014.

Pisani A, Gubellini P, Bonsi P, Conquet F, Picconi B, Centonze D, Bernardi G, Calabresi P (2001) Metabotropic glutamate receptor 5 mediates the potentiation of $\mathrm{N}$-methyl-D-aspartate responses in medium spiny striatal neurons. Neuroscience 106:579-587.

Rahman S, Neuman RS (1996) Characterization of metabotropic glutamate receptor-mediated facilitation of $N$-methyl-D-aspartate depolarization of neocortical neurons. Br J Pharmacol 117:675-683.

Rodriguez-Moreno A, Sistiaga A, Lerma J, Sanchez-Prieto J (1998) Switch from facilitation to inhibition of excitatory synaptic transmission by group I mGluR desensitization. Neuron 21:1477-1486.

Rosenmund C, Feltz A, Westbrook GL (1995) Calcium-dependent inactivation of synaptic NMDA receptors in hippocampal neurons. J Neurophysiol 73:427-430.
Salter MW (1998) Src, $N$-methyl-D-aspartate (NMDA) receptors, and synaptic plasticity. Biochem Pharmacol 56:789-798.

Salter MW (2001) LTP gets culture. Trends Neurosci 24:560-561.

Shanley LJ, Irving AJ, Harvey J (2001) Leptin enhances NMDA receptor function and modulates hippocampal synaptic plasticity. J Neurosci 21:RC186:1-6.

Shigemoto R, Kinoshita A, Wada E, Nomura S, Ohishi H, Takada M, Flor PJ, Neki A, Abe T, Nakanishi S, Mizuno N (1997) Differential presynaptic localization of metabotropic glutamate receptor subtypes in the rat hippocampus. J Neurosci 17:7503-7522.

Siciliano JC, Gelman M, Girault JA (1994) Depolarization and neurotransmitters increase neuronal protein tyrosine phosphorylation. J Neurochem 62:950-959.

Skeberdis VA, Lan J, Opitz T, Zheng X, Bennett MV, Zukin RS (2001) mGluR1-mediated potentiation of NMDA receptors involves a rise in intracellular calcium and activation of protein kinase $\mathrm{C}$. Neuropharmacology 40:856-865.

Snyder EM, Philpot BD, Huber KM, Dong X, Fallon JR, Bear MF (2001) Internalization of ionotropic glutamate receptors in response to mGluR activation. Nat Neurosci 4:1079-1085.

Swartz KJ, Bean BP (1992) Inhibition of calcium channels in rat CA3 pyramidal neurons by a metabotropic glutamate receptor. J Neurosci $12: 4358-4371$

Takasu MA, Dalva MB, Zigmond RE, Greenberg ME (2002) Modulation of NMDA receptor-dependent calcium influx and gene expression through EphB receptors. Science 295:491-495.

Trombley PQ, Westbrook GL (1992) L-AP4 inhibits calcium currents and synaptic transmission via a G-protein-coupled glutamate receptor. J Neurosci 12:2043-2050.

Ugolini A, Corsi M, Bordi F (1997) Potentiation of NMDA and AMPA responses by group I mGluR in spinal cord motor neurons. Neuropharmacology 36:1047-1055.

Valenti O, Conn PJ, Marino M (2002) Distinct physiological roles of the Gq-coupled metabotropic glutamate receptors coexpressed in the same neuronal populations. J Cell Physiol 191:125-137.

Wang XF, Daw NW, Jin X (1998) The effect of ACPD on the responses to NMDA and AMPA varies with layer in slices of rat visual cortex. Brain Res 812:186-192.

Watabe AM, Carlisle HJ, O'Dell TJ (2002) Postsynaptic induction and presynaptic expression of group I mGluR-dependent LTD in the hippocampal CA1 region. J Neurophysiol 87:1395-1403.

Xiong ZG, Pelkey KA, Lu WY, Lu YM, Roder JC, MacDonald JF, Salter MW (1999) Src potentiation of NMDA receptors in hippocampal and spinal neurons is not mediated by reducing zinc inhibition. J Neurosci 19:RC37:1-6.

Yu SP, Sensi SL, Canzoniero LM, Buisson A, Choi DW (1997) Membrane-delimited modulation of NMDA currents by metabotropic glutamate receptor subtypes $1 / 5$ in cultured mouse cortical neurons. J Physiol (Lond) 499:721-732.

Zhong J, Gerber G, Kojic L, Randic M (2000) Dual modulation of excitatory synaptic transmission by agonists at group I metabotropic glutamate receptors in the rat spinal dorsal horn. Brain Res 887:359377. 